\title{
KAJIAN KETERKAITAN ANTARA CADANGAN OKSIGEN DENGAN BEBAN BAHAN ORGANIK DI ZONA LAKUSTRIN DAN TRANSISI WADUK IR. H. DJUANDA
}

\author{
Asmika H. Simarmata'), Enan M. Adiwilaga'), Bibiana W. Lay ${ }^{3)}$, dan Tri Prartono ${ }^{3)}$ \\ 1) Mahasiswa Program Studi IImu Perairan, SPs, Institut Pertanian Bogor \\ 2) Ketua Komisi Pembimbing, Dosen Institut Pertanian Bogor \\ ${ }^{3)}$ Anggota Komisi Pembimbing, Dosen Institut Pertanian Bogor
}

Teregristrasi I tanggal: 22 Mei 2007; Diterima setelah perbaikan tanggal: 27 Desember 2007;

Disetujui terbit tanggal: 16 Januari 2008

\begin{abstract}
ABSTRAK
Kematian massal ikan pada budi daya ikan dalam karamba jaring apung di Waduk Ir. H. Djuanda hampir selalu terjadi setiap tahun. Deplesi oksigen merupakan faktor yang mempengaruhi kondisi tersebut. Oleh karena itu, penelitian ini dilakukan. Tujuan penelitian ini adalah untuk mengkaji atau menentukan kemampuan perairan dalam menerima beban bahan organik. Penelitian dilakukan di Waduk Ir. H. Djuanda dari bulan Juni 2003 sampai dengan Mei 2004, dengan interval pengambilan contoh setiap bulan. Pengambilan contoh dilakukan di wilayah lakustrin yaitu stasiun L1, L2, dan L3 dan wilayah transisi stasiun T1, T2, dan T3. Pengambilan contoh vertikal meliputi permukaan, kedalaman 7, 15, 25, dan $35 \mathrm{~m}$, dan dasar perairan. Metode dalam penelitian ini adalah survei post fakto. Analisis contoh dilakukan di laboratorium produktivitas perairan, Fakultas Perikanan dan IImu Kelautan, Institut Pertanian Bogor dan laboratorium kimia Loka Riset Pemacuan Stok Ikan, Jatiluhur. Parameter yang dianalisis adalah oksigen terlarut, bahan organik total, dan K2 (koefisien peluruhan), sedangkan parameter penunjang adalah suhu dan $\mathrm{H}_{2} \mathrm{~S}$. Hasil penelitian ini menunjukkan bahwa peningkatan bahan organik menyebabkan deplesi oksigen semakin tajam pada musim hujan di wilayah lakustrin. Konsentrasi bahan organik yang aman adalah 7,76 mg per I.
\end{abstract}

KATAKUNCI: $\quad$ oksigen, deplesi, bahan organik, Waduk Ir. H. Djuanda

ABSTRACT: The relation of dissolved oxygen reserved to organic load at Ir. H. Djuanda Reservoir Purwakarta, West Java. By: Asmika H. Simarmata, Enan M. Adiwilaga, Bibiana W. Lay, and Tri Prartono

\begin{abstract}
Mass mortality of fishes at Ir. H. Djuanda Reservoir occurs almost every year. Oxygen depletion is one factor that affect the condition. There fore, this research should be done. The carrying capacity at Ir. H. Djuanda Reservoir to receive organic loading were determined in this study. The research conducted at Ir. H. Djuanda Reservoir from June 2003 until May 2004. Horizontal sampling station was conducted based on longitudinal gradient i.e. lacustrine zone (L1, L2, and L3), and transition zone (T1, T2, and T3). Vertical sampling points were at surface, at the depth of $7 \mathrm{~m}, 15,25,35$, and 45 $m$, and at the bottom. Sample analysis carried out in physical chemical laboratory of Aquatic Resources Management Department, Faculty of Fisheries and Marine Science, IPB and chemical laboratory Loka Jatiluhur. The methods of this research were post facto survey descriptive. Dissolved oxygen, total organic matter, and BOD were observed during research.temperature and $\mathrm{H}_{2} \mathrm{~S}$ were observed to support the study. The results showed that the increasing of organic matter cause the steep of oxygen depletion in transition of wet season at lacustrine zone. Acceptable concentration of total organic matter was $7.76 \mathrm{mg}$ per $\mathrm{l}$.
\end{abstract}

KEYWORDS: $\quad$ oxygen, depletion, organic matter, Ir. H. Djuanda Reservoir

\section{PENDAHULUAN}

Waduk Ir. H. Djuanda adalah salah satu waduk terbesar di Indonesia. Sejak tahun 1976, di Waduk Ir. H. Djuanda telah dimulai kegiatan usaha budi daya ikan di karamba jaring apung. Kegiatan budi daya ikan ini mengalami perkembangan setiap tahun. Pada tahun 1999, jumlah karamba jaring apung di Waduk Ir. H.
Djuanda 2.357 unit dan pada tahun 2003 jumlah karamba jaring apung telah mencapai 3.216 unit dengan total produksi mencapai 3.145 ton per 3 bulan.

Kegiatan budi daya ikan di karamba jaring apung memberikan limbah berupa sisa pakan dan kotoran ikan yang potensial mengakibatkan deplesi oksigen di perairan. Menurut Mc Donad et al. (1996) 30\% dari 
jumlah pakan yang diberikan tertinggal sebagai pakan yang tidak dikonsumsi dan 25 sampai dengan $30 \%$ dari pakan yang dikonsumsi akan diekskresikan. Ini berarti sumbangan bahan organik dari karamba jaring apung yang diterima perairan cukup besar. Hal ini, sesuai dengan penelitian yang telah dilakukan oleh Krismono \& Krismono (2003) yang menunjukkan ketebalan endapan di daerah karamba jaring apung lebih tebal daripada di daerah bebas karamba jaring apung serta penelitian Krismono et al. (2001) mengenai dampak karamba jaring apung terhadap peningkatan unsur hara di Waduk Ir. H. Djuanda.

Beban masukkan limbah dikendalikan agar sesuai dengan daya dukung asimilasi perairan yaitu ketersediaan cadangan oksigen di hipolimnion. Dengan kata lain, keseimbangan antara input (sumber) dan output (kehilangan atau pemakaian) oksigen penting untuk menjaga agar tidak terjadi deplesi oksigen yang potensial mengakibatkan defisit oksigen di perairan.

Penelitian ini bertujuan untuk mengkaji keterkaitan ketersediaan cadangan oksigen dengan beban bahan organik sebagai dasar penentu beban masukkan limbah dari kegiatan usaha budi daya karamba jaring apung.

\section{BAHAN DAN METODE}

\section{Lokasi dan Waktu Pengambilan Contoh}

Penelitian ini dilakukan di Waduk Ir. H. Djuanda, Purwakarta Jawa Barat, dari bulan Juni 2003 sampai dengan Mei 2004. Analisis laboratorium dilakukan di Loka Riset Pemacuan Stok Ikan, Jatiluhur, Purwakarta dan laboratorium fisika kimia bagian Produktivitas Lingkungan Perairan, Fakultas Perikanan dan IImu Kelautan, Institut Pertanian Bogor. Berdasarkan pada curah hujan dan tinggi muka air selama pengamatan, maka waktu pengamatan dikelompokkan menjadi 3 musim, yaitu musim kemarau (bulan Juni sampai dengan September 2003) dengan curah hujan ratarata berkisar antara 0 sampai dengan 19,25 mm, musim hujan (bulan Pebruari sampai dengan Mei 2004) dengan curah hujan rata-rata berkisar antara 11,65 sampai dengan $30,98 \mathrm{~mm}$, dan antara musim kemarau sampai dengan hujan (bulan Oktober 2003 sampai dengan Januari 2004) dengan curah rata-rata berkisar antara 8,44 sampai dengan 31,34 mm.

\section{Metode dan Desain Pengambilan Contoh}

Metode yang digunakan dalam penelitian ini adalah deskriptif survei post facto. Penentuan stasiun pengamatan berdasarkan pada gradien longitudinal waduk dan posisi karamba jaring apung ditentukan stasiun penelitian yaitu wilayah lakustrin dan transisi. Stasiun pengamatan wilayah lakustrin ada 3 yaitu stasiun L1, L2, dan L3; stasiun pengamatan wilayah transisi T1, T2, dan T3 (Gambar 1). Pengambilan contoh vertikal meliputi permukaan, kedalaman 7, 15, 25, 35, $45 \mathrm{~m}$ dan dasar perairan. Posisi masingmasing stasiun disajikan pada Tabel 1.

\section{Pengambilan Contoh dan Pengukuran Parameter}

Bahan yang digunakan adalah contoh air yang diambil dari Waduk Ir. H. Djuanda. Parameter kualitas air yang diamati meliputi parameter fisika dan kimia. Pengukuran parameter diperoleh dengan cara mengukur langsung di lapangan dan pengambilan contoh untuk dianalisis di laboratorium. Parameter yang langsung diukur di lapangan yaitu suhu dan oksigen terlarut, sedangkan parameter lain dianalisis di laboratorium seperti tertera pada Tabel 2. Pengukuran dan analisis kualitas air mengacu pada metode menurut APHA (1989), sedangkan koefisien peluruhan (K2) diukur dengan prinsip metode $\mathrm{BOD}_{5}$, yang mana konsentrasi oksigen terlarut contoh diukur pada hari ke-0, 2, 4, 6, 8, dan 10 (Metcalf \& Eddy, 1991).

Tabel 1. Stasiun pengamatan wilayah lakustrin dan transisi serta posisi Table 1. The position of sampling station at lacustrine and transition zone

\begin{tabular}{|c|c|c|}
\hline Wilayah/Zone & Stasiun/Station & Posisi/Position \\
\hline \multirow{3}{*}{ Lakustrin } & $\mathrm{L} 1$ & $6^{\circ} 32^{\prime} 00^{\prime \prime}$ LS dan 107²1'35” BT \\
\hline & L2 & $6^{\circ} 31^{\prime} 58^{\prime \prime}$ LS dan $107^{\circ} 20^{\prime} 45^{\prime \prime}$ BT \\
\hline & L3 & 6³1'00" LS dan 107²1'35" BT \\
\hline \multirow[t]{3}{*}{ Transisi } & T1 & $6^{\circ} 33^{\prime} 11,6^{\prime \prime}$ LS dan $107^{\circ} 23^{\prime} 48,6^{\prime \prime}$ BT \\
\hline & T2 & $6^{\circ} 33^{\prime} 00^{\prime \prime}$ LS dan $107^{\circ} 23^{\prime} 15^{\prime \prime}$ BT \\
\hline & T3 & 6³4'2,6” LS dan $107^{\circ} 23^{\prime} 56,8^{\prime \prime}$ BT \\
\hline
\end{tabular}




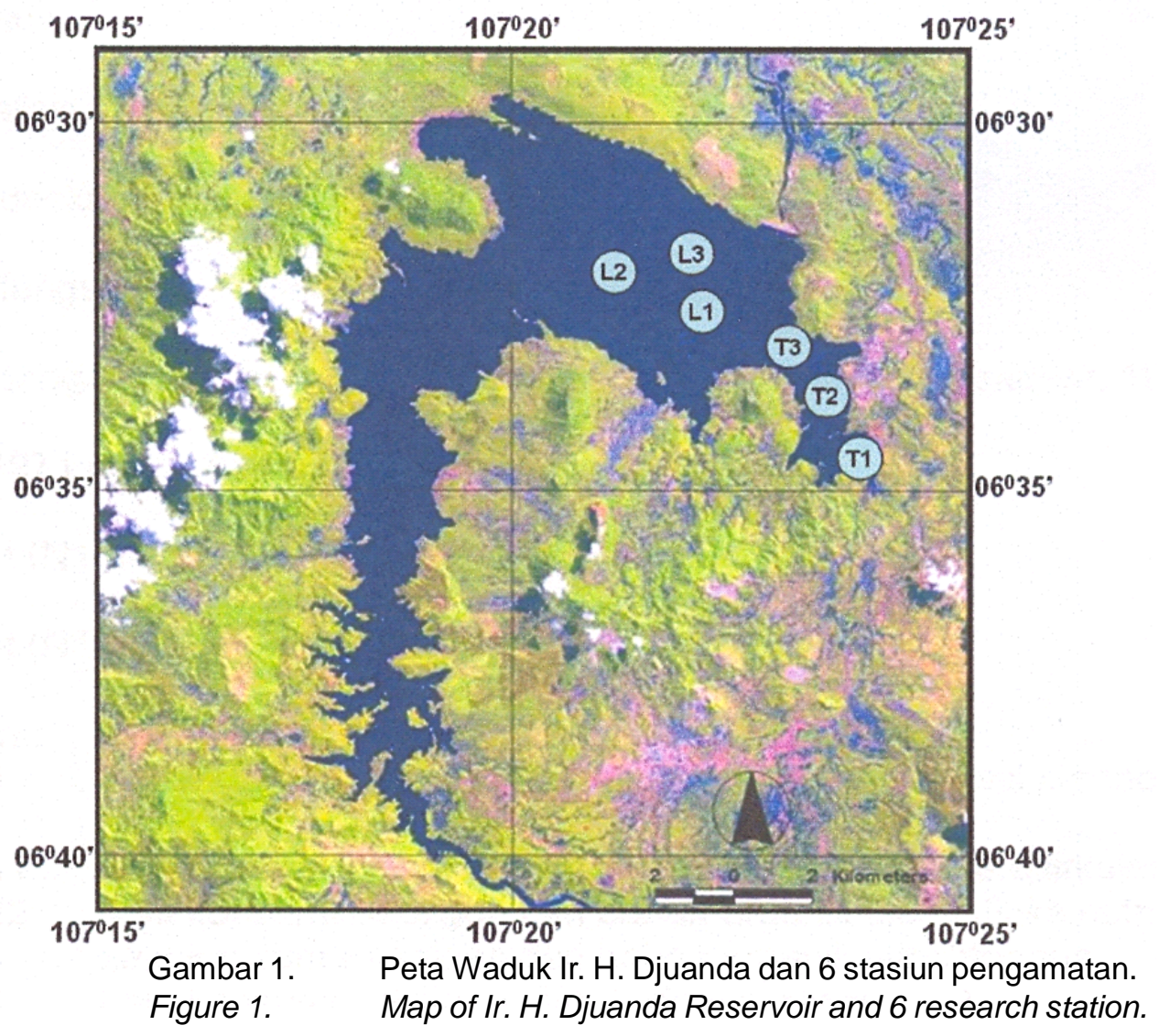

Tabel2. Parameter, metode, unit, dan tempat analisis selama penelitian Table 2. Parameter, method, unit, and analyse place during research

\begin{tabular}{|c|c|c|c|c|}
\hline & Parameter/Parameter & Unit/Unit & Metode/Method & $\begin{array}{l}\text { Tempat analisis/ } \\
\text { Place of analysis }\end{array}$ \\
\hline \multirow[t]{2}{*}{ A. } & Fisika & & & \\
\hline & Suhu & ${ }^{\circ} \mathrm{C}$ & Pemuaian/Thermometer $\mathrm{Hg}$ & In situ \\
\hline & Kimia & & & \\
\hline & DO & $\mathrm{mg} / \mathrm{l}$ & Modifikasi Winkler & In situ \\
\hline & Вот & $\mathrm{mg} / \mathrm{l}$ & $\mathrm{KMnO}_{4} /$ Buret & Laboratorium \\
\hline \multirow[t]{2}{*}{ C. } & Biologi & & & \\
\hline & Koefisien Peluruhan (K2) & - & Botol gelap & Laboratorium \\
\hline
\end{tabular}

\section{Analisis Data}

Analisis data meliputi analisis deskripsi kimia dan analisis fungsional.

Cadangan oksigen terlarut hipolimnion (DORS menurut Jernelov (1971) dalam Landner (1976):

$\mathrm{R}-\mathrm{t}(\mathrm{N} 1+\mathrm{N} 2+\mathrm{A}+\mathrm{B})>0$ di mana:

R : Cadangan oksigen terlarut di hipolimnion pada awal stagnasi

$\mathrm{t}$ : Lama waktu stagnasi

N1 : $\quad$ Laju konsumsi oksigen oleh bahan organik yang teresirkulasi

N2 : Laju konsumsi oksigen oleh bahan organik oleh influks nutrien

A : Laju konsumsi oksigen oleh bahan organik allochtonous

B : Laju konsumsi oksigen oleh sedimen dasar 
dimodifikasi menjadi:

$$
\mathrm{R}-\mathrm{t}(\mathrm{N} 1+\mathrm{N} 2+\mathrm{A})>0
$$

Pada penelitian ini $(\mathrm{N} 1+\mathrm{N} 2+\mathrm{A})$ diperoleh dengan pengukuran $\mathrm{BOD}_{5}$.

Defisit Oksigen diperoleh berdasarkan pada perhitungan:

$$
\mathrm{DOt}_{1}-\mathrm{K} 2[\ln \{(\mathrm{BOT} 1+\mathrm{BOT} 2) / 2\}] \times 30
$$

di mana:

$\begin{array}{ll}\mathrm{DOt}_{1} & : \text { DO pada waktu } \mathrm{t}-1 \\ \mathrm{~K}_{1} & : \text { Koefisien peluruhan } \\ \text { BOT1 } & : \text { BOT pada waktu } \mathrm{t}-1 \\ \text { BOT2 } & : \text { BOT pada waktu t-2 } \\ 30 & : \begin{array}{l}\text { : } \\ \text { dalam } 1 \text { bulan) }\end{array}\end{array}$

Analisis hubungan antara konsentrasi oksigen terlarut dan bahan organik total sebagai berikut:

$\mathrm{Y}=\mathrm{Y}_{0}+\beta_{1} \mathrm{X}_{1}$

di mana:

$\mathrm{Y}$ : Konsentrasi DO (mg per I)

$Y_{0}$ : Konstanta

$\beta_{1}$ : Slope atau kemiringan

$X_{1}$ : Bahan organik total (mg per I)

\section{HASIL DAN BAHASAN}

\section{Oksigen Terlarut (DO)}

Konsentrasi oksigen terlarut selama pengamatan menunjukkan pola yang cenderung hampir sama. Pada umumnya konsentrasi DO di permukaan relatif lebih besar dibanding kedalaman di bawah. Pada musim hujan konsentrasi DO di permukaan dan kedalaman $7 \mathrm{~m}$ relatif lebih besar dibanding pada musim kemarau dan antara kemarau sampai dengan hujan (Gambar 2).

Profil vertikal DO berkurang dengan bertambah kedalaman. Pada musim kemarau, konsentrasi oksigen di permukaan berkisar antara 1,33 sampai dengan $9,04 \mathrm{mg}$ per I, antara musim kemarau sampai dengan hujan berkisar antara 3,38 sampai dengan $11,82 \mathrm{mg}$ per I, dan pada musim hujan berkisar antara 6,10 sampai dengan $12,95 \mathrm{mg}$ per I. Pada kedalaman $7 \mathrm{~m}$ berturut-turut dari musim kemarau, antara musim kemarau sampai dengan hujan dan musim hujan yaitu 1,09 sampai dengan $5,27 \mathrm{mg}$ per $\mathrm{l} ; 0,27$ sampai dengan $6,87 \mathrm{mg}$ per I, dan 0,71 sampai dengan $8,76 \mathrm{mg}$ per I.

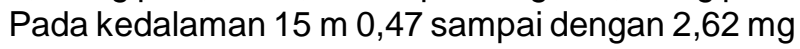
per I; 0 sampai dengan 3,26 mg per I; dan 0 sampai dengan $1,18 \mathrm{mg}$ per I; dan pada kedalaman $25 \mathrm{~m} 0$ sampai dengan 1,67 mg per I; 0 sampai dengan 2,13 $\mathrm{mg}$ per I; dan 0 sampai dengan $0,47 \mathrm{mg}$ per I. Di permukaan konsentrasi oksigen terendah $1,33 \mathrm{mg}$ per I ditemukan pada bulan Juli dan tertinggi $12,95 \mathrm{mg}$ per I pada bulan Mei. Pada kedalaman $7 \mathrm{~m}$, konsentrasi $\mathrm{DO}$ terendah $0,27 \mathrm{mg}$ per I pada bulan Januari di stasiun T3, sedangkan tertinggi $8,76 \mathrm{mg}$ per I pada bulan Mei di stasiun T2.

Selanjutnya, di kedalaman $15 \mathrm{~m}$, konsentrasi terendah $0 \mathrm{mg}$ per I dan tertinggi 3,26 mg per I pada bulan Oktober (di stasiun L3), serta di kedalaman 25 $\mathrm{m}$, terendah $0 \mathrm{mg}$ per I dan tertinggi 2,13 $\mathrm{mg}$ per I juga pada bulan Oktober di stasiun L3. Konsentrasi oksigen terlarut berfluktuasi dan cenderung meningkat pada musim hujan baik di lakustrin maupun transisi.

Tabel3. Uji two way anova DO antar kedalaman dan antar waktu di wilayah lakustrin dan transisi Waduk Ir. H. Djuanda

Table 3. Test two way anova of dissolved oxygen between depth and time in lacustrine and transition

\begin{tabular}{|c|c|c|c|c|c|c|}
\hline \multirow{2}{*}{$\begin{array}{l}\text { Stasiun/ } \\
\text { Station }\end{array}$} & \multicolumn{2}{|c|}{$\begin{array}{c}\text { Musim kemarau/ } \\
\text { Dry season }\end{array}$} & \multicolumn{2}{|c|}{$\begin{array}{l}\text { Antara musim kemarau-hujan/ } \\
\text { Within dry and wet season }\end{array}$} & \multicolumn{2}{|c|}{$\begin{array}{c}\text { Musim hujan/ } \\
\text { Wet season }\end{array}$} \\
\hline & $\begin{array}{c}\text { Kedalaman/ } \\
\text { Depth }\end{array}$ & $\begin{array}{c}\text { Waktu/ } \\
\text { Time }\end{array}$ & $\begin{array}{l}\text { Kedalaman/ } \\
\text { Depth }\end{array}$ & $\begin{array}{l}\text { Waktu/ } \\
\text { Time }\end{array}$ & $\begin{array}{l}\text { Kedalaman } \\
\text { Depth }\end{array}$ & $\begin{array}{c}\text { Waktu } \\
\text { Time }\end{array}$ \\
\hline L1 & $S$ & TS & $S$ & TS & $S$ & TS \\
\hline L2 & $S$ & TS & $S$ & TS & $S$ & TS \\
\hline L3 & $S$ & TS & $S$ & TS & $S$ & TS \\
\hline $\mathrm{T} 1$ & $S$ & TS & $S$ & TS & $S$ & TS \\
\hline $\mathrm{T} 2$ & $S$ & TS & $S$ & TS & $S$ & TS \\
\hline T3 & TS & $S$ & - & - & $\mathrm{S}$ & $\mathrm{S}$ \\
\hline
\end{tabular}
zone at Ir. H. Djuanda Reservoir

Keterangan/Remarks: Kedalaman = kedalaman (permukaan 7, 15, dan 25 m); S =signifikan (pada $\alpha=95 \%$ ); TS = tidak signifikan (pada $\alpha=95 \%$ ); - = stasiun menjadi daratan; waktu = bulan Juni sampai dengan September (musim kemarau); bulan Oktober sampai dengan Januari (antara musim kemarau sampai dengan hujan); bulan Pebruari sampai dengan Mei (musim hujan) 

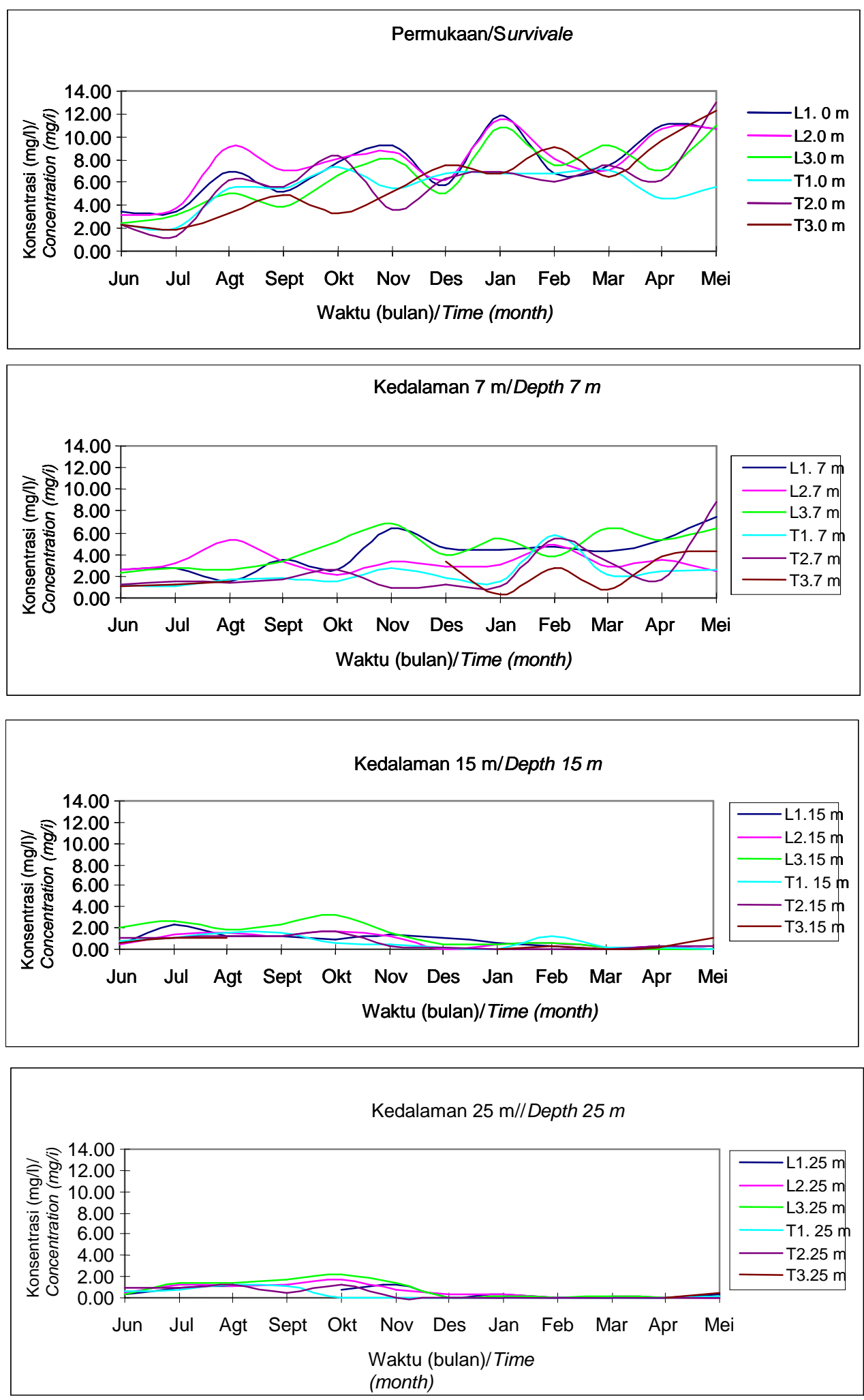

Gambar 2.

Figure 2.

Konsentrasi oksigen terlarut (mg per I) di Waduk Ir. H. Djuanda.

Dissolved oxygen concentration (mg per l) at Ir. H. Djuanda Reservoir. 
Uji two way anova antar kedalaman (permukaan, 7,15 , dan $25 \mathrm{~m}$ ) di wilayah lakustrin signifikan pada $\alpha=95 \%$, tetapi antar waktu tidak signifikan. Di wilayah transisi stasiun T1 dan T2, konsentrasi DO signifikan antar kedalaman $(\alpha=95 \%)$ baik musim kemarau maupun hujan tetapi antar waktu tidak signifikan. Di stasiun T3 pada musim hujan, konsentrasi DO antar kedalaman dan antar waktu berbeda nyata pada $\alpha=95 \%$ seperti disajikan pada Tabel 3 .
Uji two way anova antar stasiun dalam wilayah yang sama menunjukkan stasiun L1, L2, dan L3 permukaan signifikan pada $\alpha=95 \%$ pada musim kemarau dan antara musim kemarau sampai dengan hujan. Pada kedalaman $7 \mathrm{~m}$, antar stasiun tidak signifikan kecuali antara musim kemarau sampai dengan hujan. Selanjutnya, pada kedalaman $15 \mathrm{~m}$ antar stasiun, signifikan hanya pada musim kemarau dan antar waktu pada musim hujan. Di kedalaman $25 \mathrm{~m}$, antar stasiun terlihat DO tidak signifikan. Selanjutnya, di wilayah transisi uji two way anova menunjukkan bahwa

Tabel 4. Uji two way anova DO antar stasiun dan antar waktu pada berbagai kedalaman di wilayah lakustrin dan transisi Waduk Ir. H. Djuanda

Table 4. Test two way anova of dissolved oxygen between station and time at each depth in lacustrine and transition zone at Ir. H. Djuanda Reservoir

\begin{tabular}{|c|c|c|c|c|c|c|c|}
\hline \multirow{2}{*}{$\begin{array}{l}\text { Wilayah/ } \\
\text { Zone }\end{array}$} & \multirow{2}{*}{$\begin{array}{l}\text { Kedalaman/ } \\
\text { Depth } \\
\text { (m) }\end{array}$} & \multicolumn{2}{|c|}{$\begin{array}{c}\text { Musim kemarau/ } \\
\text { Dry season }\end{array}$} & \multicolumn{2}{|c|}{$\begin{array}{c}\text { Antara musim } \\
\text { kemarau-hujan/ } \\
\text { Within dry and wet season }\end{array}$} & \multicolumn{2}{|c|}{$\begin{array}{l}\text { Musim hujan/ } \\
\text { Wet season }\end{array}$} \\
\hline & & $\begin{array}{c}\text { Stasiun/ } \\
\text { Station }\end{array}$ & $\begin{array}{c}\text { Waktu/ } \\
\text { Time }\end{array}$ & $\begin{array}{c}\text { Stasiun/ } \\
\text { Station }\end{array}$ & $\begin{array}{c}\text { Waktu/ } \\
\text { Time }\end{array}$ & $\begin{array}{l}\text { Stasiun/ } \\
\text { Station }\end{array}$ & $\begin{array}{c}\text { Waktu/ } \\
\text { Time }\end{array}$ \\
\hline \multirow[t]{4}{*}{ Lakustrin } & 0,5 & $S$ & $S$ & $S$ & $S$ & TS & TS \\
\hline & 7 & TS & TS & $S$ & TS & TS & TS \\
\hline & 15 & $S$ & TS & TS & TS & TS & $S$ \\
\hline & 25 & TS & $S$ & TS & $S$ & TS & TS \\
\hline \multirow[t]{4}{*}{ Transisi } & 0,5 & TS & TS & TS & TS & TS & TS \\
\hline & 7 & TS & TS & $\mathrm{TS}^{*}$ & TS* & TS & TS \\
\hline & 15 & TS & TS & $\mathrm{TS}^{*}$ & $\mathrm{TS}^{*}$ & TS & TS \\
\hline & 25 & $\mathrm{TS}^{*}$ & $\mathrm{TS}^{*}$ & $\mathrm{TS}^{*}$ & TS* & TS & TS \\
\hline
\end{tabular}

Keterangan/Remarks: Kedalaman = kedalaman; $S=$ signifikan (pada $\alpha=95 \%)$; TS = tidak signifikan (pada $\alpha=95 \%) ;{ }^{*}=u j i$ hanya dilakukan di stasiun T1dan T2; Waktu = bulan Juni sampai dengan September (musim kemarau); bulan Oktober sampai dengan Januari (antara musim kemarau sampai dengan hujan); bulan Pebruari sampai dengan Mei (musim hujan)

antar stasiun T1, T2, dan T3 tidak signifikan baik itu musim kemarau, hujan, atau antara musim kemarau sampai dengan hujan; demikian juga antar waktu seperti disajikan pada Tabel 4.

Konsentrasi DO rata-rata di permukaan selama pengamatan relatif tinggi (3,32 sampai dengan 8,93 mg per I) dibanding kedalaman di bawah (Tabel 5). Pada kedalaman $7 \mathrm{~m}$, konsentrasi DO rata-rata berkisar antara 1,44 sampai dengan $4,78 \mathrm{mg}$ per I, di kedalaman $15 \mathrm{~m}$ berkisar antara 0,22 sampai dengan $1,64 \mathrm{mg}$ per I dan pada kedalaman $25 \mathrm{~m}$ berkisar antara 0,06 sampai dengan $1,06 \mathrm{mg}$ per $\mathrm{I}$. Jadi terlihat bahwa oksigen cukup tersedia hanya di lapisan atas. Menurut Schmittou (1991), ikan budi daya akan hidup dengan layak bila kandungan oksigen terlarut yang tersedia di perairan lebih besar dari $3 \mathrm{mg}$ per I. Apabila ditentukan konsentrasi DO kecil dari $3 \mathrm{mg}$ per I adalah konsentrasi kritis, maka di lapisan tengah wilayah lakustrin, konsentrasi oksigen sudah pada titik kritis.
Selanjutnya, Cornett \& Rigler (1984) dalam Matthew \& Effler (2006), yang mengatakan pada konsentrasi oksigen terlarut lebih kecil dari 2 sampai dengan 3 mg per $L$ akan menyebabkan deplesi yang rendah. Dalam penelitian ini terlihat bahwa pada musim kemarau rata-rata konsentrasi oksigen terlarut lebih kecil dari 2 sampai dengan $3 \mathrm{mg}$ per I setelah kedalaman $7 \mathrm{~m}$ (Tabel 5).

Sementara itu, di wilayah transisi pada kedalaman $7 \mathrm{~m}$, baik musim kemarau maupun antara musim kemarau sampai dengan hujan konsentrasi DO lebih kecil dari $2 \mathrm{mg}$ per I, atau lebih kecil dari syarat yang dibutuhkan untuk kebutuhan budi daya ikan. Ini berarti pada kedalaman $7 \mathrm{~m}$, perairan telah mengalami kondisi anoksik atau anaerob, sedangkan di wilayah lakustrin kondisi anoksik ditemukan mulai pada kedalaman $15 \mathrm{~m}$. Kondisi di wilayah transisi ini disebabkan oleh pengaruh aktivitas karamba jaring apung. 
Konsentrasi oksigen terlarut rata-rata permukaan dan kedalaman $7 \mathrm{~m}$ di wilayah lakustrin pada musim antara musim kemarau sampai dengan hujan dan musim hujan relatif lebih besar dibanding musim kemarau. Hal ini, sehubungan dengan konsentrasi bahan organik yang relatif lebih besar pada musim kemarau (6.926 mg per I) dibanding antara musim kemarau sampai dengan hujan (5.121 mg per I) dan musim hujan (6.206 mg per l) sehingga dibutuhkan lebih banyak oksigen untuk proses dekomposisi aerobik.

Pada musim kemarau, penurunan DO paling tajam ditemukan di stasiun L1 (bulan Agustus) dan T1 (bulan September). Antara musim kemarau sampai dengan hujan, penurunan paling tajam ditemukan pada bulan
Januari di lakustrin dan bulan Oktober di transisi, dan pada musim hujan ditemukan pada bulan April di lakustrin dan bulan Pebruari di transisi.

Selanjutnya, jika dihubungkan dengan suhu, pada musim hujan suhu permukaan relatif lebih kecil dibanding musim kemarau dan antara musim kemarau sampai dengan hujan. Di wilayah lakustrin misal ratarata suhu permukaan pada musim hujan $29,5^{\circ} \mathrm{C}$ relatif lebih kecil dibanding suhu rata-rata musim kemarau $29,7^{\circ} \mathrm{C}$ dan antara musim kemarau sampai dengan hujan $30,6^{\circ} \mathrm{C}$. Demikian juga, di wilayah transisi ratarata suhu permukaan pada suhu musim hujan $29,5^{\circ} \mathrm{C}$, musim kemarau $30,0^{\circ} \mathrm{C}$ dan antara musim kemarau sampai dengan hujan $30,7^{\circ} \mathrm{C}$. Suhu yang lebih rendah

Tabel 5. Konsentrasi oksigen rata-rata per musim di wilayah lakustrin dan transisi di Waduk Ir. $\mathrm{H}$. Djuanda

Table 5. The average concentration of dissolved oxygen every seasons in lacustrine and transition zone at Ir. H. Djuanda Reservoir

\begin{tabular}{|c|c|c|c|c|}
\hline $\begin{array}{l}\text { Wilayah/ } \\
\text { Zone }\end{array}$ & $\begin{array}{l}\text { Kedalaman/ } \\
\text { Depth }(\mathrm{m})\end{array}$ & $\begin{array}{l}\text { Musim kemarau/ } \\
\text { Dry season }\end{array}$ & $\begin{array}{l}\text { Antara musim kemarau-hujan/ } \\
\text { Within dry and wet season }\end{array}$ & $\begin{array}{l}\text { Musim hujan/ } \\
\text { Wet season }\end{array}$ \\
\hline \multirow[t]{4}{*}{ Lakustrin } & 0,5 & $4,72 \mathrm{mg}$ per I & $8,32 \mathrm{mg}$ per I & $8,93 \mathrm{mg}$ per I \\
\hline & 7 & 2,99 mg per I & 4,24 mg per I & 4,78 mg per I \\
\hline & 15 & $1,64 \mathrm{mg}$ per I & $1,11 \mathrm{mg}$ per I & $0,22 \mathrm{mg}$ per I \\
\hline & 25 & 1,06 mg per I & 0,75 mg per I & $0,06 \mathrm{mg}$ per I \\
\hline \multirow[t]{4}{*}{ Transisi } & 0,5 & 3,32 mg per I & 6,20 mg per I & $7,88 \mathrm{mg}$ per I \\
\hline & 7 & 1,44 mg per I & 1,74 mg per I & $3,64 \mathrm{mg}$ per I \\
\hline & 15 & 1,46 mg per I & $0,43 \mathrm{mg}$ per I & $0,32 \mathrm{mg}$ per I \\
\hline & 25 & $0,94 \mathrm{mg}$ per I & 0,17 mg per I & $0,11 \mathrm{mg}$ per I \\
\hline
\end{tabular}

dan ada agitasi permukaan pada musim hujan menyebabkan kelarutan oksigen relatif lebih besar. Konsentrasi DO permukaan yang lebih tinggi pada musim hujan dan antara musim kemarau sampai dengan hujan mengakibatkan oksigen yang merambat ke lapisan di bawah lebih besar dibanding musim kemarau yang konsentrasi DO relatif lebih kecil.

Hasil penelitian ini menunjukkan beban bahan organik di Waduk Ir. H. Djuanda sudah sangat besar, yang berasal dari sisa pakan aktivitas karamba jaring apung. Krismono \& Krismono (2003) telah mengamati bahwa ketebalan endapan di daerah budi daya lebih tebal $10 \mathrm{~cm}$ dibandingkan dengan daerah tanpa budi daya. Dampak penurunan kualitas air juga telah diamati dari hasil penelitian sebelum berupa sebaran vertikal oksigen di daerah dari bulan Juni sampai dengan Desember 1996, dengan konsentrasi DO minimum pada kedalaman $30 \mathrm{~m}$ yaitu $2,9 \mathrm{mg}$ per I tetapi tidak pernah ditemukan konsentrasi oksigen nol (Krismono et al., 2001). Pada penelitian ini konsentrasi DO di kedalaman $7 \mathrm{~m}$ kecil dari $3 \mathrm{mg}$ per I dan pada kedalaman $15 \mathrm{~m}$ sudah tidak ditemukan oksigen (di wilayah lakustrin). Hal ini, menunjukkan bahwa kedalaman lapisan oksik pada penelitian ini semakin berkurang dibanding kedalaman lapisan oksik pada tahun 1996, yang artinya terjadi peningkatan akumulasi bahan organik dibanding dengan penelitian sebelum.

Penurunan konsentrasi oksigen terlarut pada suatu perairan seperti kasus Waduk Ir. H. Djuanda merupakan fenomena yang terjadi pada perairan dengan akumulasi bahan organik yang tinggi. Hal ini, disebabkan oleh pemanfaatan oksigen terlarut untuk proses dekomposisi melalui metabolisme organisme akuatik. Proses dekomposisi yang terjadi tergantung pada jumlah oksigen di permukaan sedimen dan di interfase apabila bakteri yang berperan adalah bakteri heterotrofik aerobik. Pada kondisi oksigen terlarut yang relatif terbatas dibanding dengan jumlah bahan organik seperti di perairan Waduk Ir. H. Djuanda, akan 
mengakibatkan kondisi anaerobik. Ketiadaan oksigen terlarut ini tidak berarti proses dekomposisi berhenti, tetapi terus berlangsung dengan memanfaatkan oksidator lain yang ada di dalam waduk seperti sulfat, nitrat, mangan oksida, dan besi $\left(\mathrm{Fe}^{+3}\right)$. Pemanfaatan sulfat dan nitrat dalam proses dekomposisi anaerobik akan menghasilkan gas $\mathrm{H}_{2} \mathrm{~S}$ dan amonia $\left(\mathrm{NH}_{3}\right)$ yang bersifat toksik bagi organisme perairan. Hal ini, dapat dilihat pada bulan Juni, konsentrasi $\mathrm{H}_{2} \mathrm{~S}$ di kolom air tinggi (>1 mg per l) dan konsentrasi oksigen terlarut yang relatif rendah (<3 mg per l) serta konsentrasi bahan organik total rata-rata kolom air yang tinggi. Semakin banyak bahan organik, maka proses dekomposisi anaerobik akan semakin meningkatkan konsentrasi $\mathrm{H}_{2} \mathrm{~S}$ di dalam air. Hal ini, terindikasi dengan munculnya gas-gas toksik seperti $\mathrm{H}_{2} \mathrm{~S}$ yang tinggi pada bulan tertentu.

\section{Bahan Organik Total}

Konsentrasi bahan organik total selama pengamatan berfluktuasi. Konsentrasi tertinggi ditemukan pada bulan Juni dan terendah pada bulan Nopember (Gambar 3). Hal ini, sehubungan dengan pengenceran yang berasal dari beban hidrolik, yang mana peningkatan volume air pada bulan Nopember lebih besar 1,7 kali dibanding bulan lain. Selanjutnya, konsentrasi bahan organik rata-rata pada musim kemarau lebih besar dibanding musim hujan baik di lakustrin maupun transisi. Di wilayah lakustrin konsentrasi bahan organik total rata-rata terendah $4.029 \mathrm{mg}$ per I ditemukan pada musim antara musim kemarau sampai dengan hujan dan tertinggi 8.533 mg per I pada musim kemarau. Sementara itu, di transisi rata-rata bahan organik total terendah

Tabel 6. Konsentrasi bahan organik total rata-rata ( $\mathrm{mg}$ per I) selama pengamatan di wilayah lakustrin dan transisi Waduk Ir. H. Djuanda

Table 6. The average concentration of total organic matter during research in lacustrine and transition zone at Ir. H. Djuanda Reservoir

\begin{tabular}{|c|c|c|c|c|c|c|c|c|c|}
\hline \multirow{2}{*}{$\begin{array}{c}\text { Kedalaman/ } \\
\text { Depth }(\mathrm{m})\end{array}$} & \multicolumn{3}{|c|}{$\begin{array}{l}\text { Musim kemarau/ } \\
\text { Dry season }\end{array}$} & \multicolumn{3}{|c|}{$\begin{array}{l}\text { Antara musim kemarau-hujan/ } \\
\text { Within dry and wet season }\end{array}$} & \multicolumn{3}{|c|}{$\begin{array}{l}\text { Musim hujan/ } \\
\text { Wet season }\end{array}$} \\
\hline & L1 & L2 & L3 & L1 & L2 & L3 & L1 & L2 & L3 \\
\hline 0,5 & 7.031 & 6.399 & 7.937 & 5.530 & 5.290 & 5.333 & 7.360 & 8.374 & 4.977 \\
\hline 7 & 6.557 & 8.533 & 5.924 & 4.029 & 4.582 & 4.108 & 7.347 & 6.083 & 4.977 \\
\hline 15 & 6.004 & 5.846 & 5.490 & 4.582 & 5.688 & 6.794 & 6.557 & 5.371 & 5.135 \\
\hline \multirow[t]{2}{*}{25} & 11.269 & 5.924 & 6.201 & 4.503 & 5.609 & 5.411 & 6.280 & 6.873 & 5.135 \\
\hline & $\mathrm{T} 1$ & T2 & T3 & $\mathrm{T} 1$ & T2 & T3 & $\mathrm{T} 1$ & T2 & T3 \\
\hline 0,5 & 5.175 & 6.865 & 5.214 & 6.873 & 6.320 & 6.597 & 6.083 & 4.424 & 5.135 \\
\hline 7 & 6.004 & 5.530 & 5.628 & 5.056 & 5.648 & 5.214 & 4.740 & 5.293 & 5.214 \\
\hline 15 & 4.857 & 7.070 & 6.531 & 5.925 & 6.043 & - & 4.582 & 8.374 & 4.188 \\
\hline 25 & 7.308 & 7.781 & - & 5.421 & 5.767 & - & 5.965 & 5.609 & 4.424 \\
\hline
\end{tabular}

Keterangan/Remarks: - = stasiun menjadi daratan; Ked. = kedalaman; $\mathrm{L}=$ stasiun wilayah lakustrin; $\mathrm{T}=$ stasiun wilayah transisi

ditemukan pada musim hujan (4.188 mg per I). Pada umumnya konsentrasi bahan organik total lebih besar pada musim kemarau dibanding musim hujan seperti tertera pada Tabel 6.

Tabel 7.

Uji two way anova bahan organik total antar kedalaman dan antar waktu di wilayah lakustrin dan transisi Waduk Ir. H. Djuanda

Table 7. Test two way anova of total organic matter between depth and time in lacustrine and transition zone at Ir. H. Djuanda Reservoir

\begin{tabular}{ccccccc}
\hline \multirow{2}{*}{$\begin{array}{c}\text { Stasiun/ } \\
\text { Station }\end{array}$} & \multicolumn{2}{c}{$\begin{array}{c}\text { Musim kemarau/ } \\
\text { Dry season }\end{array}$} & \multicolumn{2}{c}{$\begin{array}{c}\text { Antara musim kemarau-hujan/ } \\
\text { Within dry and wet season }\end{array}$} & \multicolumn{2}{c}{$\begin{array}{c}\text { Musim hujan/ } \\
\text { Wet season }\end{array}$} \\
\cline { 2 - 7 } & $\begin{array}{c}\text { Kedalaman/ } \\
\text { Depth }\end{array}$ & $\begin{array}{c}\text { Waktu/ } \\
\text { Time }\end{array}$ & $\begin{array}{c}\text { Kedalaman/ } \\
\text { Depth }\end{array}$ & $\begin{array}{c}\text { Waktu/ } \\
\text { Time }\end{array}$ & $\begin{array}{c}\text { Kedalaman/ } \\
\text { Depth }\end{array}$ & $\begin{array}{c}\text { Waktu/ } \\
\text { Time }\end{array}$ \\
\hline L1 & TS & TS & TS & S & TS & S \\
L2 & TS & TS & TS & S & TS & S \\
L3 & TS & TS & TS & S & TS & S \\
T1 & TS & TS & TS & S & TS & TS \\
T2 & TS & TS & TS & S & TS & TS \\
T3 & TS & S & - & - & TS & S \\
\hline
\end{tabular}

Keterangan/Remarks: Ked. = kedalaman (permukaan 7, 15, dan 25 m); S = signifikan (pada $\alpha=95 \%$ ); TS = tidak signifikan (pada $\alpha=95 \%) ; \quad-=$ stasiun menjadi daratan 

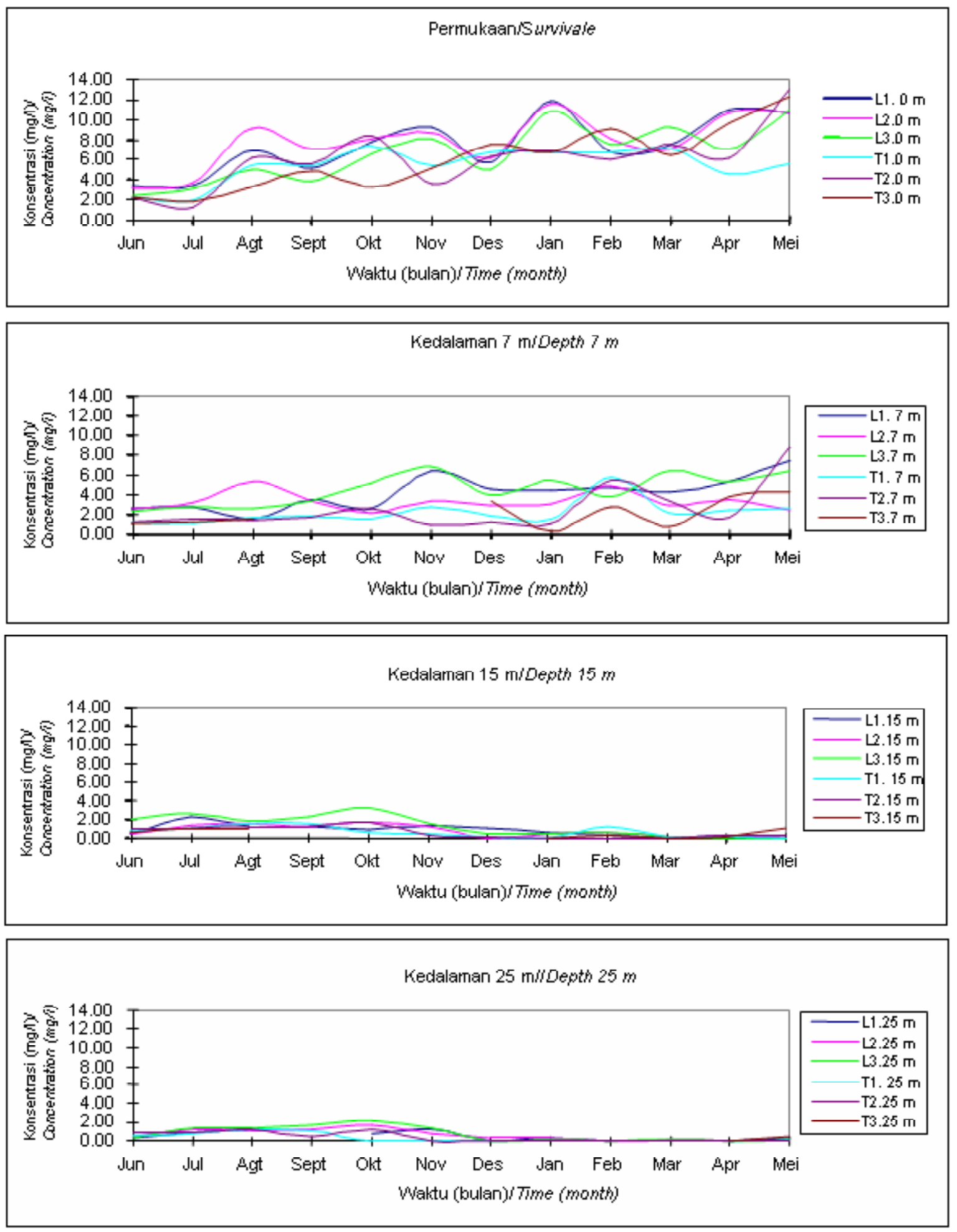

Gambar 3. Konsentrasi bahan organik total (mg per I) dari bulan Juni 2003 sampai dengan Mei 2004 di stasiun wilayah lakustrin dan transisi Waduk Ir. H. Djuanda.

Figure 3. Concentration of total organic matter from June 2003 to May 2004 at lacustrine and transition zone Djuanda Reservoir. 
Uji dengan two way anova konsentrasi bahan organik total di masing-masing stasiun menunjukkan antar kedalaman tidak siginifikan pada $\alpha=95 \%$ pada semua musim (Tabel 7). Selanjutnya, antar waktu terlihat bahwa antara musim kemarau sampai dengan hujan, signifikan pada $\alpha=95 \%$ di semua stasiun dan pada musim hujan signifikan di semua stasiun kecuali di stasiun T1 dan T2.
Di transisi distribusi temporal bahan organik total berbeda nyata antar waktu yakni pada musim antara musim kemarau sampai dengan hujan, sedangkan di lakustrin konsentrasi bahan organik total berbeda nyata pada musim hujan dan antara musim kemarau sampai dengan hujan.

Tabel 8. Uji two way anova bahan organik total antar stasiun dan antar waktu di wilayah lakustrin dan transisi Waduk Ir. H. Djuanda

Table 8. Test two way anova of total organic matter between station and time in lacustrine and transition zone at Ir. H. Djuanda Reservoir

\begin{tabular}{|c|c|c|c|c|c|c|c|}
\hline \multirow{2}{*}{$\begin{array}{l}\text { Wilayah/ } \\
\text { Zone }\end{array}$} & \multirow{2}{*}{$\begin{array}{l}\text { Kedalaman/ } \\
\operatorname{Depth}(\mathbf{m})\end{array}$} & \multicolumn{2}{|c|}{$\begin{array}{c}\text { Musim kemarau/ } \\
\text { Dry season }\end{array}$} & \multicolumn{2}{|c|}{$\begin{array}{c}\text { Antara musim } \\
\text { kemarau-hujan/ Within dry and } \\
\text { wet season }\end{array}$} & \multicolumn{2}{|c|}{$\begin{array}{l}\text { Musim hujan/ } \\
\text { Wet season }\end{array}$} \\
\hline & & $\begin{array}{c}\text { Stasiun/ } \\
\text { Station }\end{array}$ & $\begin{array}{c}\text { Waktu/ } \\
\text { Time }\end{array}$ & $\begin{array}{c}\text { Stasiun/ } \\
\text { Station }\end{array}$ & $\begin{array}{l}\text { Waktu/ } \\
\text { Time }\end{array}$ & $\begin{array}{c}\text { Stasiun/ } \\
\text { Station }\end{array}$ & $\begin{array}{c}\text { Waktu/ } \\
\text { Time }\end{array}$ \\
\hline \multirow[t]{4}{*}{ Lakustrin } & 0 & TS & TS & TS & S & TS & TS \\
\hline & 7 & TS & TS & TS & $S$ & TS & TS \\
\hline & 15 & TS & TS & TS & $S$ & TS & TS \\
\hline & 25 & TS & $S$ & TS & TS & TS & TS \\
\hline \multirow[t]{4}{*}{ Transisi } & 0 & TS & $S$ & TS & $S$ & TS & TS \\
\hline & 7 & TS & TS & $\mathrm{TS}^{*}$ & $S^{*}$ & TS & $S$ \\
\hline & 15 & TS & TS & $\mathrm{TS}^{*}$ & $S^{*}$ & TS & TS \\
\hline & 25 & $\mathrm{TS}^{*}$ & $S^{*}$ & $\mathrm{TS}^{*}$ & $\mathrm{~S}^{*}$ & TS & TS \\
\hline
\end{tabular}

Keterangan/Remarks: Waktu = bulan Juni sampai dengan September (musim kemarau); bulan Oktober sampai dengan Januari (antara musim kemarau sampai dengan hujan); bulan Pebruari sampai dengan Mei (musim hujan); Ked. = kedalaman $(\mathrm{m}) ; \mathrm{S}=\mathrm{signifikan}$ (pada á=95\%); TS = tidak signifikan (pada á=95\%); * = uji dilakukan hanya di stasiun T1 dan T2

Uji two way anova antar stasiun terlihat konsentrasi bahan organik total tidak signifikan baik di permukaan, kedalaman 7, 15, dan $25 \mathrm{~m}$. Antar waktu antara musim kemarau sampai dengan hujan bahan organik total signifikan hampir di semua kedalaman kecuali di wilayah lakustrin pada kedalaman 25 m (Tabel 8).

Jadi distribusi spasial bahan organik total selama pengamatan tidak signifikan antar kedalaman, demikian juga antar stasiun dalam wilayah yang sama. Tetapi distribusi temporal signifikan yaitu antara musim kemarau sampai dengan hujan baik di lakustrin maupun di transisi. Hal ini, menunjukkan bahwa musim mempengaruhi jumlah beban bahan organik di perairan.

Berdasarkan pada konsentrasi bahan organik total dan nilai koefisien peluruhan (Simarmata, 2007), diperoleh nilai defisit DO. Nilai koefisien peluruhan berkisar antara 0,04 sampai dengan 0,21 di wilayah lakustrin dan 0,03 sampai dengan 0,15 di wilayah transisi. Defisit DO kolom air di wilayah lakustrin pada musim kemarau relatif lebih besar dibanding wilayah transisi. Sementara itu, antara musim kemarau sampai dengan hujan, di permukaan wilayah lakustrin maupun transisi tidak terjadi defisit DO (Tabel 9). Selanjutnya, pada musim hujan di wilayah transisi (permukaan dan kedalaman $7 \mathrm{~m}$ ) tidak terjadi defisit
DO. Tetapi pada musim yang sama di lakustrin terjadi defisit di seluruh kolom air. Defisit yang relatif besar di wilayah lakustrin sesuai dengan beban bahan organik yang juga lebih besar di lakustrin dibanding transisi.

Apabila konsentrasi oksigen terlarut dan bahan organik total di masing-masing wilayah diplot (bahan organik total sebagai $x$ dan oksigen terlarut sebagai y) akan diperoleh persamaan. Di lakustrin, kemiringan yang cukup besar ditemukan antara musim kemarau sampai dengan hujan demikian juga di wilayah transisi seperti ditunjukkan pada Gambar 4 dan 5 . Hubungan antara bahan organik total dan konsentrasi oksigen terlarut setiap musim menunjukkan ada kecenderungan penurunan DO dengan bertambah konsentrasi bahan organik total. Hal ini, sesuai dengan pendapat Van Dolah \& Anderson (1991); Mallin et al., 2002 dalam Mallin et al. (2006) yang mengatakan hipoksia kronis atau anoksia dapat disebabkan oleh beban organik dari sumber allochtonous. Selanjutnya, Wetzel (2001) mengatakan bahwa hipoksia kronis sering disebabkan oleh proses autochtonous di dalam badan air.

Dari persamaan hubungan bahan organik total dan konsentrasi oksigen terlarut ini, diperoleh konsentrasi 
Tabel 9. Defisit oksigen (mg per I) antar waktu di kolom air wilayah lakustrin dan transisi Waduk Ir. H. Djuanda

Table 9. The temporal oxygen deficits ( $\mathrm{mg}$ per l) of water column in lacustrine and transition zone at Ir. H. Djuanda Reservoir

\begin{tabular}{ccccc}
\hline $\begin{array}{c}\text { Wilayah/ } \\
\text { Zone }\end{array}$ & $\begin{array}{c}\text { Kedalaman/ } \\
\text { Depth }(\mathbf{m})\end{array}$ & $\begin{array}{c}\text { Musim kemarau/ } \\
\text { Dry season }\end{array}$ & $\begin{array}{c}\text { Antara musim kemarau-hujan/ } \\
\text { Within dry and wet season }\end{array}$ & $\begin{array}{c}\text { Musim hujan/ } \\
\text { Wet season }\end{array}$ \\
\hline Lakustrin & 0,5 & 0,18 & 0,70 & $-5,37$ \\
& 7 & $-2,67$ & $-1,88$ & $-7,35$ \\
& 15 & $-3,41$ & $-2,02$ & $-2,08$ \\
& 25 & $-5,53$ & $-0,95$ & $-3,38$ \\
& 35 & & $-2,33$ & $-4,17$ \\
& Dasar & & & $-4,82$ \\
Transisi & Rata-rata & $-2,86$ & $-1,30$ & $-4,53$ \\
& 0,5 & 0,66 & 3,04 & 4,53 \\
& 7 & $-1,57$ & $-0,69$ & 1,17 \\
& 15 & $-0,97$ & $-1,95$ & $-2,45$ \\
& 25 & $-1,57$ & $-5,84$ & $-7,30$ \\
& 35 & & $-6,23$ & $-5,13$ \\
& Dasar & & & $-5,59$ \\
\hline
\end{tabular}

Keterangan/Remarks: Ked. = kedalaman $(\mathrm{m})$
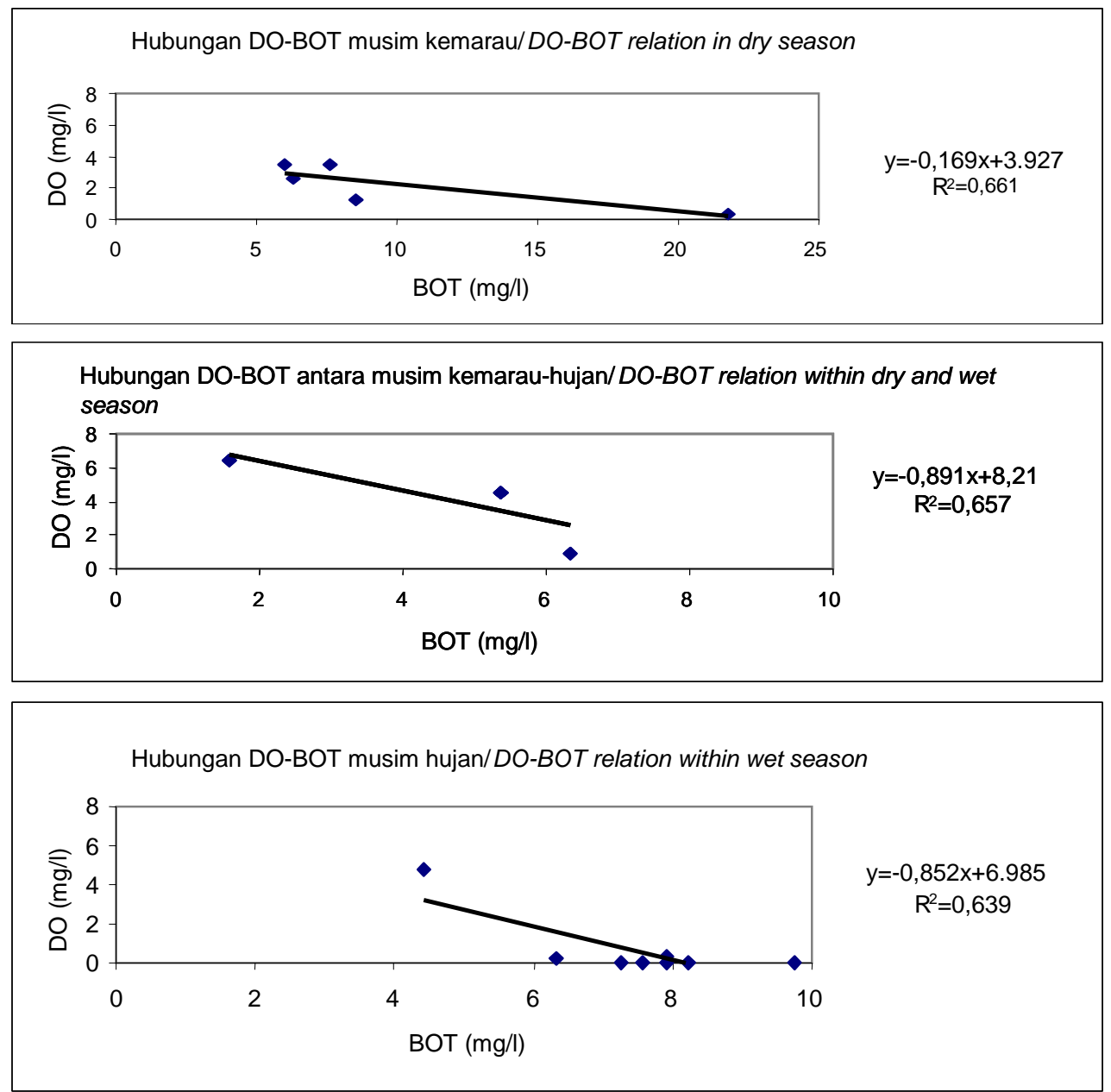

Gambar 4. Hubungan konsentrasi oksigen terlarut (DO) dan bahan organik total di stasiun L1 Waduk Ir. H. Djuanda.

Figure 4. The relation of dissolved oxygen concentration to total organic matter in station L1 at Ir. H. Djuanda Reservoir. 

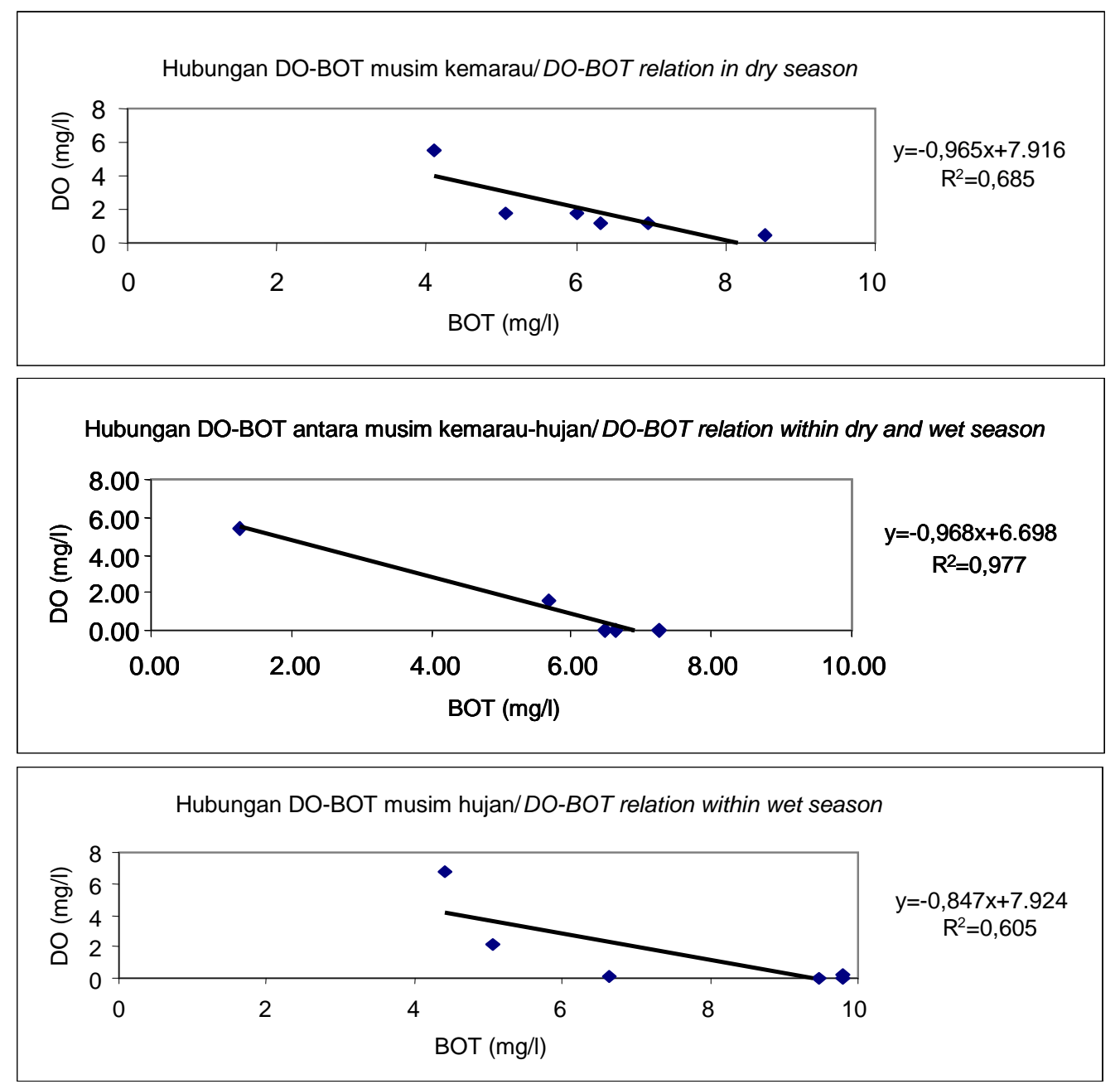

Gambar 5. Hubungan konsentrasi oksigen terlarut (DO) dan bahan organik total di stasiun T1 Waduk Ir. H. Djuanda.

Figure 5. The relation of dissolved oxygen concentration to total organic matter in station $T 1$ at Ir. $H$. Djuanda Reservoir.

bahan organik total maksimum kolom air yang dapat diterima di wilayah lakustrin pada musim kemarau $5,49 \mathrm{mg}$ per I, antara musim kemarau sampai dengan hujan $5,85 \mathrm{mg}$ per I, dan pada musim hujan $4,68 \mathrm{mg}$ per I. Di transisi konsentrasi bahan organik total maksimum pada musim kemarau, antara musim kemarau sampai dengan hujan dan hujan berturutturut 5,09; 3,82; dan 6,72 mg per I.

Berdasarkan pada beban bahan organik, cadangan oksigen terlarut dan koefisien peluruhan terlihat bahwa distribusi oksigen bervariasi sepanjang tahun. Di wilayah transisi misal terlihat hubungan antara bahan organik dan cadangan oksigen terlarut kuat antara musim kemarau sampai dengan hujan (dilihat dari nilai R).

Ketersediaan oksigen terlarut di waduk dipengaruhi oleh gradien kedalaman waduk yang artinya material yang terbawa dari perairan dangkal (riverin) akan sampai dengan ke perairan dalam (wilayah lakustrin), sehingga konsentrasi oksigen terlarut sangat ditentukan oleh seberapa besar bahan organik yang boleh ada di wilayah transisi yang dapat didukung oleh wilayah lakustrin. Berdasarkan pada hal ini diperoleh konsentrasi bahan organik total yang dapat diterima (bahan organik total aman) $4,48 \mathrm{mg}$ per I musim kemarau, 7,76 mg per I antara musim kemarau sampai dengan hujan dan 4,24 mg per I musim hujan di wilayah transisi (Tabel 10). Apabila beban bahan organik di transisi lebih besar daripada konsentrasi tersebut, maka akan menyebabkan DO kritis di wilayah lakustrin.

Berdasarkan pada konsentrasi bahan organik total aman tersebut di atas, maka dapat disebutkan bahwa konsentrasi bahan organik total di transisi pada musim kemarau dan hujan telah melebihi dari daya dukung 
perairan. Dengan kata lain, beban pada musim ini telah menyebabkan DO kritis di perairan. Bahan organik yang dapat diterima oleh perairan adalah atau diizinkan di wilayah transisi 7,76 mg per I.

Defisit DO terbesar ditemukan di wilayah lakustrin (4,53 $\mathrm{mg}$ per I) pada musim hujan. Apabila dibandingkan antar wilayah terlihat defisit DO di lakustrin lebih besar dibanding wilayah transisi, kecuali antara musim kemarau sampai dengan hujan, defisit DO wilayah transisi (2,41 mg per I) lebih besar dibanding wilayah lakustrin (1,30 mg per I). Hal ini, disebabkan oleh konsentrasi bahan organik pada musim antara kemarau sampai dengan hujan di wilayah transisi relatif lebih tinggi dibanding di wilayah lakustrin.

Defisit DO selama pengamatan menunjukkan ketersediaan DO yang tidak cukup disebabkan oleh beban bahan organik yang berlebihan. Hal ini, karena sumber oksigen sangat terbatas.

Tabel 10. Bahan organik total, daya dukung dan defisit DO di wilayah lakustrin dan transisi Waduk Ir. H. Djuanda

Table 10. Total organic matter, carrying capacity, and DO deficits in lacustrine and transition zone at Ir. H. Djuanda Reservoir

\begin{tabular}{lcccc}
\hline \multirow{2}{*}{$\begin{array}{c}\text { Musim/ } \\
\text { Season }\end{array}$} & KOT/BOT & $\begin{array}{c}\text { Kaysentrasi/Concentration (mg per I) } \\
\text { Carring capacity }\end{array}$ & $\begin{array}{c}\text { Defisit DO/ } \\
\text { DO defisit }\end{array}$ & $\begin{array}{c}\text { BOT aman/ } \\
\text { Savety BOT }\end{array}$ \\
\cline { 2 - 5 } & 6.956 & 5.489 & 2,86 & \\
\hline L. musim kemarau & 5.159 & 5.854 & 1,30 & \\
L. antara K-H & 6.152 & 4.682 & 4,53 & 4,48 \\
L. musim hujan & 6.197 & & 0,86 & 7,76 \\
T. musim kemarau & 6.131 & & 2,41 & 4,24 \\
T. antara K-H & 5.697 & & 2,46 & \\
T. musim hujan & & & & \\
\hline
\end{tabular}

Keterangan/Remarks: $\mathrm{L}=$ Lakustrin; $\mathrm{T}=$ Transisi; $\mathrm{K}-\mathrm{H}=$ Kemarau Hujan

\section{KESIMPULAN}

1. Dari pengukuran kualitas air selama penelitian di Waduk Ir. H. Djuanda terutama berdasarkan pada profil vertikal oksigen terlarut dan bahan organik menunjukkan bahwa telah terjadi deplesi oksigen yang mengakibatkan defisit oksigen di perairan. Hampir sepanjang pengamatan terjadi defisit DO.

2. Ada inidikasi bahwa aktivitas budi daya ikan dalam karamba jaring apung menyebabkan penurunan kualitas perairan terutama berkurang lapisan oksik di wilayah transisi. Berdasarkan pada beban bahan organik dan kemampuan perairan dalam menerima beban, maka waktu yang relatif aman untuk budi daya ikan di karamba jaring apung adalah dari bulan Oktober sampai dengan Januari. Konsentrasi bahan organik yang boleh atau diizinkan di wilayah transisi 7,76 mg per I.

\section{SARAN}

1. Perlu dikaji sumbangan beban bahan organik oleh karamba jaring apung setiap pola tanam.
2. Untuk mengetahui yang paling signifikan menghabiskan oksigen di perairan sebaiknya dilakukan penelitian mengenai kebutuhan respirasi oleh ikan dan kebutuhan oksigen oleh sedimen.

3. Pada saat tinggi muka air minimum, padat tebar ikan di karamba jaring apung sebaiknya dikurangi atau diganti dengan jenis ikanyang lebih toleran terhadap konsentrasi DO yang rendah.

\section{UCAPAN TERIMA KASIH}

Tulisan ini merupakan bagian dari penelitian disertasi penulis yang dilakukan di Waduk Ir. $\mathrm{H}$. Djuanda dari bulan Juni 2003 sampai dengan Mei 2004 dengan judul kajian keterkaitan antara cadangan oksigen dengan beban masukkan bahan organik di Waduk Ir. H. Djuanda Purwakarta, Jawa Barat. Penelitian ini dibantu dana dari BPPS dan juga Bapak Endi Setiadi Kartamihardja. Ucapan terima kasih disampaikan pada Direktorat Jenderal Dikti Departemen Pendidikan Nasional atas bantuan dana penelitiannya (melalui beasiswa BPPS) dan juga pada Bapak Endi Setiadi Kartamihardja serta staf Loka Riset Pemacuan Stok Ikan, Jatiluhur. 


\section{PERSANTUNAN}

Kegiatan dari hasil riset kajian keterkaitan antara cadangan oksigen dengan beban masukkan bahan organik di Waduk Ir. H. Djuanda Purwakarta, Jawa Barat, T.A. 2003-2004, di BPPS.

\section{DAFTAR PUSTAKA}

American Public Health Association. 1989. Standard method for examination of water and waste water. $14^{\text {th }}$ Ed. APHA-AWWA-WPFC. Port Press. Washington DC.

Krismono, A. S. N. \& Krismono. 2003. Indikator umbalan dilihat dari aspek kualitas air di perairan Waduk Djuanda, Jatiluhur, Jawa Barat.

Landner, L. 1976. Eutrophication of lakes. World Health Organization Regional Office for Europe.

Mallin, M. A., V. L. Johnson, S. H. Ensign, \& T. A. Mac Pherson. 2006. Factors contributing to hypoxia in rivers, lakes, and streams. Limnology Oceanography. 51 (1, part 2). 690-701. American Society of Limnology and Oceanography. Inc.

Matthew, D. A. \& S. W Effler. 2006. Long-term changes in the areal hypolimnetic oxygen deficit of Onondaga Lake: Evidence of sediment feedback. Limnology Oceanography. 51 (1, part 2). 702-714.
American Society of Limnology and Oceanography. Inc.

Mc. Donald, M. E., Tikkanen C. A., Axler R. P., Larsen, C. P., \& Host, G. 1996. Fish simulation culture modek (FIS-C): A bioenergetics based model for aquacultural wasteload application. Aquacultural Engineering. 15 (4). 243-259.

Metcalf \& Eddy. 1991. Waste water engineering. Mc Graw Hill International Edition Civil Engineering Series. New York.

Nastiti, A. S. K., Krismono, \& E. S. Kartamiharja. 2001. Dampak budi daya ikan dalam karamba jaring apung terhadap peningkatan unsur $\mathrm{N}$ dan $\mathrm{P}$ di perairan Waduk Saguling, Cirata, dan Jatiluhur. Jurnal Penelitian Perikanan Indonesia. Vol.7 (2). 22-30.

Wetzel, R. G. 2001. Limnology lake and river ecosytem. $3^{\text {rd }}$ Ed. Academic Press. London.

Simarmata, A. H. 2007. Kajian keterkaitan antara kemantapan cadangan dengan beban bahan organik di Waduk Ir. H. Djuanda Purwakarta. Jawa Barat.

Schmittou, H. R. 1991. Cage culture: A method of fish production in Indonesia. FRDP. Central Research Institute for Fisheries. Jakarta. 